been digging since the 7 th, but in vain. His corpse will not be found until the spring. Meanwhile his widow is lying in a house which overlooks the place where her husband was overwhelmed. Avalanches have descended on both sides of the hill on which this homestead stands. The gorge which separates Davos from Wiesen, called the "Züge," or the "Paths of Avalanches," is a mere wilderness of snow shot down from either side."

That the weather this winter on the Continent has been exceptionally severe is still further shown by the following extracts from long and numerous newspaper reports :-

"Heavy snowfalls were again reported yesterday from the central districts of Northern Italy, where it is stated that in some places the snow is as much as ten feet deep. The Alpine troops with the Carabineers, under the direction and leadership of the authorities, have been working heroically in the task of rescuing the people of the small villages which have been buried in the masses of snow. By the latest accounts more than 200 bodies had been taken out. The hamlet of Trasquera, in Piedmont, at the foot of the Simplon, has been completely overwhelmed by an avalanche. In the Bini valley five persons have been killed by an avalanche.

"The strange coincidence of a violent thunderstorm and a heavy fall of snow occurring at the same time took place on Saturday morning in the Giant Mountains near Gorlitz, in Silesia.

"Two avalanches have fallen on the famous hospice of St. Bernard. The church has been almost entirely buried in snow."

(Communicated by C. Davies Sherborn, F.G.S.)

\title{
NOTICES OF MEMTOIRS.
}

I.-Titanichthys pharao, nov. gen. et nov. sp., AUS DER KREIDEFormation Aegrptens. By Prof. Dr. W. Dames. Sitzungsb. Ges. naturf. Freunde Berlin, 1887, pp. 69-72, woodcuts.

QOME detached and partially broken teeth from the Lower Seno. D nian of Egypt are described by Dr. Dames under the name of Titanichthys pharao. The specimens were obtained by Dr. Schweinfurth about 10 kilometres west of the Pyramids of Gizeh, and, when complete, measure 60 millim. in length. They are laterally-compressed teeth, with a very long root, rapidly tapering upwards, and marked by deep longitudinal furrows. The enamelled crown is relatively small, and of an unsymmetrical arrow-head shape, overhanging the summit of the root in front and behind, and thus giving the tooth a barbed character. The genus thus imperfectly indicated is regarded as new, and placed (with Enchodus) in the Trichiuridre; if really undescribed, however, it will require another name, Titanichthys having been preoccupied by Newberry for a huge Placoderm (Trans. New York Acad. 1885). 
II.-Die Gattung Saurodon, Hays. By Prof. Dr. W. Dames. Ibid. pp. $72-78$.

URING the investigation of the teeth of Titanichthys, Dr. Dames was led to study the semi-barbed teeth from the European Chalk originally referred by Agassiz to the American genus and species Saurodon Leanus, Hays. The result is an interesting resume of the varied fate of the fossils in question at the hands of different palæontologists. Their resemblance to the teeth of the Trichiuridæ is discussed, and full references are given to the several descriptions and figures. It is unfortunate, however, that Hays' original memoir has not been consulted, nor yet the most important contributions of Leidy (Trans. Amer. Phil. Soc. vol, xi.) and E. T. Newton (Quart. Journ. Geol. Soc. vol. xxxiv.). The latter authors have shown that the European fossils are certainly not referable to Saurocephalus (of which Saurodon is a synonym), and those from the English Chalk are named Cimolichthys levesiensis.

A. S. W.

卫巴叉IEW S.

I.-Geologr, Chemical, Physical, and Stratigraphical. By Joseph Prestwich, M.A., F.R.S., F.G.S. In Two Volumes. Vol. II. Stratigraphical and Physical. Royal 8vo. pp. xxviii. and 606, with Geological Map of Europe, and numerous Illustrations. (Oxford, at the Clarendon Press, 1888.)

I $F$ the number of geological papers published every year in 1 various parts of the globe were taken as a measure of the increase of our knowledge, our sentiments on the subject might fitly find utterance in the word "Prodigious!" Nevertheless, while this great "talus heap of geological literature," as it has been rather irreverently termed, may at times produce a feeling of dismay and oppression, yet we may derive comfort from the thought that in due course of time the leading facts and the general results of this mass of information are tabulated and expounded in the larger Text-Books and Manuals.

Our advances in geological knowledge are then best gauged by such works as the one now before us, written as it is by one of our geological leaders, and whose object it is to exhibit the present state of the science. It might indeed be maintained that we are already well supplied with Manuals of Geology-Physical, Stratigraphical, and Palæontological; but it may also fairly be urged that one individual might devote bis whole time to the literature past and present, and never learn a tithe of all that has been done in geology. Consequently the deficiencies of one work are compensated by others: and while we give honoured places on our bookshelves to the general Manuals of the older geologists-to Buckland, Bakewell, Trimmer, De la Beche, Phillips, Lyell, and Jukes, the value of whose works is now to a large extent historical ; so alongside of Geikie, Green, Seeley, and Etheridge, we accord a hearty welcome to the two handsome volumes by the ex.Professor of Geology at Oxford. 